\title{
Modelling the accumulation of PSP toxins in Thau Lagoon oysters (Crassostrea gigas) from trials using mixed cultures of Alexandrium catenella and Thalassiosira weissflogii
}

\author{
Patrick Lassus ${ }^{1}$, Zouher Amzil ${ }^{1}$, Régis Baron ${ }^{2}$, Véronique Séchet ${ }^{1}$, Laurent Barillé ${ }^{3}$, Eric Abadie ${ }^{4}$, \\ Michèle Bardouil ${ }^{1}$, Manoella Sibat ${ }^{1}$, Philippe Truquet $^{1}$, Jean-Baptiste Bérard ${ }^{1}$ and Marielle Gueguen ${ }^{1}$ \\ IFREMER, EMP, BP 21105, 44311 Nantes Cedex 3, France \\ 2 IFREMER, STAM, BP 21105, 44311 Nantes Cedex 3, France \\ 3 Université de Nantes, Laboratoire d'Ecophysiologie marine intégrée, EA 2663, Faculté des Sciences et des Techniques, BP 92208 , \\ 44322 Nantes Cedex 3, France \\ ${ }^{4}$ IFREMER, LERLR, Station de Sète, avenue Jean Monnet, BP 171, 34203 Sète Cedex, France
}

Received 16 October 2006; Accepted 12 January 2007

\begin{abstract}
In October and November 2003 a bloom of the toxic dinoflagellate Alexandrium catenella was observed in the North-east zone of Thau lagoon (French Mediterranean coast). Sea water samples were collected every hours to evaluate time-related variations of phytoplankton concentrations and to compare the relative ratio of A. catenella versus other phytoplankton species during the outbreak. From these observations, trials using recirculated sea water systems were performed to: i) evaluate the physiological effects on oyster of increasing proportions of A. catenella within a mixed microalgal diet where the non-toxic diatom Thalassiosira weissfogii was present at concentration: 1500 cells ml ${ }^{-1}$, ii) compare the effect of two temperatures $\left(12{ }^{\circ} \mathrm{C}\right.$ and $\left.18{ }^{\circ} \mathrm{C}\right)$ on paralytic toxin accumulation rates in oyster flesh by ion-pairing high performance liquid chromatography (IP-HPLC) detection, iii) analyse toxin biotransformation during the contamination process, iv) evaluate the role of the different types of oyster tissue on the bioaccumulation mechanism.

The results showed: i) a significant effect of temperature increase on clearance rate and toxin uptake, ii) no detectable time-related effects of toxic algal food on pre-ingestion sorting or on toxin profiles in oyster flesh, iii) either negative or positive effects of $A$. catenella concentrations on toxin uptake ("threshold" effect), iv) high amounts of toxins in the digestive gland, accounting for more than $80 \%$ of overall shellfish toxicity. The daily amount of toxins $\left(Q_{\text {tox }}\right)$ taken up by each oyster was evaluated by means of a global one-compartment model. However a two-compartment model finally gave the best match with real contamination kinetics, since it integrated both toxins sequestered in oyster tissues and toxins moving in through the digestive tract.
\end{abstract}

Key words: Paralytic shellfish poisoning / Crassostrea gigas / Model / toxin content / Alexandrium catenella / Mediterranean Sea

Résumé - Modélisation de l'accumulation de toxines PSP dans les huîtres (Crassostrea gigas) de l'étang de Thau à partir d'essais utilisant des cultures mixtes d'Alexandrium catenella et Thalassiosira weissflogii. En octobre et novembre 2003, une prolifération du dinoflagellé toxique Alexandrium catenella a été observée dans la partie nord-est de l'étang de Thau (côtes méditerranéennes françaises). Des échantillons d'eau ont été prélevés toutes les heures pour évaluer les variations de concentration en phytoplancton au cours du temps et pour comparer le rapport entre A. catenella et les autres espèces phytoplanctoniques au cours de cet épisode. A partir de ces observations, des expériences en circuit fermé ont été mises en place de façon à i) comparer l'incidence sur la physiologie des huîtres de proportions croissantes d'A. catenella dans un régime dominé par une diatomée nanoplanctonique, Thalassiosira weissflogii, à la concentration de 1500 cellules $\mathrm{ml}^{-1}$, ii) comparer les effets de deux températures $\left(12\right.$ et $\left.18{ }^{\circ} \mathrm{C}\right)$ sur les cinétiques de bioaccumulation de toxines paralysantes dans la chair des huîtres par détection en chromatographie en phase liquide à haute pression par échange d'ions, iii) analyser la biotransformation des toxines au cours du processus de contamination, iv) évaluer le rôle des différents tissus dans le mécanisme de bioaccumulation. Les résultats mettent en évidence un effet significatif d'une augmentation de température sur le taux de rétention et de bioaccumulation des toxines paralysantes; une absence d'effet de la nourriture toxique sur le tri pré-ingestif ou sur le profil toxinique au cours du temps; des effets positifs ou négatifs de la concentration cellulaire en A. catenella (notion de seuil) sur la bioaccumulation de toxines, et enfin une forte bioaccumulation dans la glande digestive, qui explique plus de $80 \%$ de 
la toxicité globale du coquillage. La quantité journalière de toxine $\left(Q_{\text {tox }}\right)$ prélevée par chaque huître est estimée à l'aide d'un modèle global à un compartiment. Cependant, un modèle à deux compartiments permet d'obtenir une meilleure simulation des cinétiques observées de contamination, dans la mesure où il intègre à la fois les toxines liées aux tissus des huîtres et le flux de toxines dans le tractus digestif.

\section{Introduction}

Paralytic Shellfish Toxins (PST) producing microalgae were observed in the Mediterranean Sea as early as 1978, and later on in 1985 and 1988, especially along Moroccan coasts (Lassus et al. 1999). In 1994, PSP-like intoxications in humans recorded in this country were undoubtedly connected to consumption of shellfish feeding on toxic Gymnodinium catenatum (Joutei et al. 1998). The first PSP human intoxications related to blooms of dinoflagellate belonging to the Alexandrium genus were observed in Italy in 1994 along Adriatic coasts. The culprit species was A. minutum (Honsell et al. 1996). A. catenella toxic blooms are mentioned for the first time in connection with the Spanish Catalonian coast-line in the course of the summers of 1998 and 1999 (Vila et al. 2001). Cell concentrations reached one million cells $\mathrm{L}^{-1}$ and the maximum toxicity recorded in mussels was $983 \mu \mathrm{g}$ STX (saxitoxin) equivalent $100 \mathrm{~g}^{-1}$ shellfish flesh. A similar case was noted later on in 2001, and then again in Fangar Bay (Ebro delta) but with a maximum toxicity of $298 \mu \mathrm{g}$ STX eq. $100 \mathrm{~g}^{-1}$ (Delgado comm. pers.) in mussels whereas oysters collected in the same area were not contaminated, or only contaminated at a level lower than the safe threshold ( $80 \mu \mathrm{g}$ STX eq. $100 \mathrm{~g}^{-1}$ ). Vila et al. (2001) put forward the hypothesis that this toxic species was gradually spreading along the Catalonian coastline.

Prior to 1998, the Alexandrium tamarense / A. catenella complex was rarely observed in French coastal waters, and whenever it was observed, concentrations were invariably low. However, a short term peak concentration of A. catenella of up to 20000 cells L ${ }^{-1}$, was once recorded in Thau lagoon (1995), but without any apparent harmful effects upon either marine fauna, or human consumption.

From 1998 to 2004 several PSP contamination episodes of bivalve molluscs were observed in Thau lagoon. Toxic levels exceeding the regulatory threshold were notably observed in the autumn (October-November) in mussels (Mytilus galloprovincialis), clams (Ruditapes decussatus) and sporadically in farmed Pacific oysters (Crassostrea gigas). Maximum concentrations in each shellfish species were respectively 850, 574 and $318 \mu \mathrm{g}$ STX eq. $100 \mathrm{~g}^{-1}$. Despite some taxonomic confusion arising between A.tamarense and A. catenella (Masselin et al. 2001), it is now widely agreed that the Alexandrium strain involved in contamination outbreaks is undoubtedly $A$. catenella, and that its genetic analysis reveals strong homology with Asian Alexandrium strains (Lilly et al. 2002).

The sudden outbreak in 1998 of a new toxic Alexandrium species along French coasts, especially in ecologically fragile areas such as Mediterranean coastal lagoons, focused attention on a few questions in particular as to its possible impact on shellfish farming areas. In terms of Public Health hazards the following questions were highly relevant: i) has the Alexandrium toxin profile any specific effect on saxitoxin (and gonyautoxin) retention in bivalve tissues (slow detoxification rate)? ii) have co-occurring non-toxic phytoplankton species any seasonal impact on filter-feeder contamination scores?

To answer these questions it was necessary to study each of the parameters assumed to modify paralytic toxin accumulation pathways in Thau Lagoon shellfish individually. The Pacific oyster Crassostrea gigas was chosen as the reference biological material owing to its high economic value, and the particular social and economic challenges oyster farming in Thau Lagoon presents. The scientific approach was identical to the one already adopted in a previous study conducted on the A. minutum oyster contamination mechanism in the Penzé Estuary (Northern Brittany, France) in 2001 (Lassus et al. 2004; Baron et al. 2006).

\section{Methods}

\subsection{Sampling area}

Thau Lagoon (Fig. 1) is located SW of the city of Montpellier (on the French Mediterranean coast). This $75 \mathrm{~km}^{2}$ coastal lagoon has a mean depth of $4.5 \mathrm{~m}$, and is fed by a $280 \mathrm{~km}^{2}$ hydrographic basin, namely the Pallas and Vène Rivers. Water exchanges between Thau Lagoon and the Mediterranean sea take place via the Sète and Quilles canals, and via the Pisse-Saume grau for the SW area (grau is a local term used specifically to denote channels leading into, and out of brackishwater lakes or other stretches of water in the Languedoc region). The largest share of the total water exchange with the sea takes place via the Sète canal. Angle Creek, located to the NW, has been identified as the primary sourcing area for $A$. catenella cell proliferation during the Fall blooms, since a dormant cyst population seeding on the bottom was detected some years ago (Laabir et al. 2004). About $20 \%$ of the lagoon surface is devoted to a typical " $t a-$ ble" oyster farming activity, with an annual production figure of 40000 tons per year.

\subsection{In situ phytoplankton sampling}

When A. catenella cell concentrations were at least equal to, or exceeding, $10^{4}$ cells $\mathrm{L}^{-1}$ water samples were collected every hour during a $24 \mathrm{~h}$ period. The $250 \mathrm{ml}$ water samples were lugol preserved and stored for further observation and counting of planktonic microflora with an inverted microscope (Utermöhl method). Temperature and salinity measurements were performed in real time with WTW thermoconductimeter, while continuous fluorescence recordings were obtained using a Turner Design Fluorometer. All sampling operations were performed from a small anchoring boat equipped with a power generating unit at a working station localized $43^{\circ} 26^{\prime} 73.5^{\prime \prime} \mathrm{N}$ and $3^{\circ} 39^{\prime} 43.3^{\prime \prime}$ E. Depth at the sampling site was $-4 \mathrm{~m}$. Surface and bottom water samples were respectively collected at $-1 \mathrm{~m}$ and $-3 \mathrm{~m}$. 


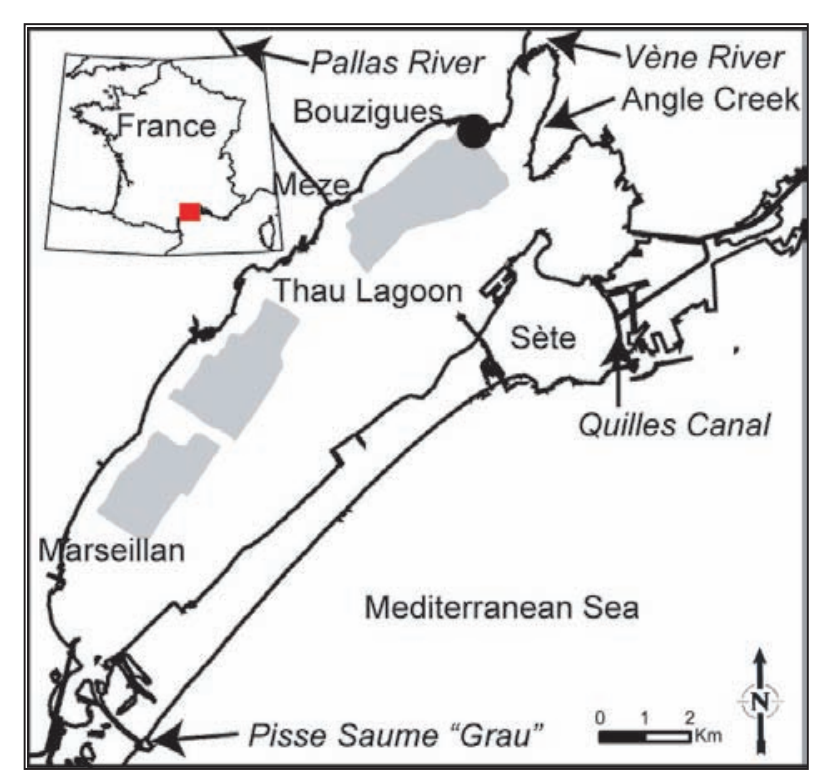

Fig. 1. General geographical situation of Thau Lagoon, oyster bed localization (grey squares) and 24-hour survey stations (black plain circles).

\subsection{Biological material}

To avoid technical problems linked to oyster spawning, triploid animals were obtained directly from South Brittany or Vendée oyster farmers. After removal of the epibiontes, the animals (flesh wet weight: $9.1 \pm 1.6 \mathrm{~g}$ ) were acclimated for 3 to 4 days in natural seawater at $16 \pm 0.5{ }^{\circ} \mathrm{C}$ before being transferred into experimental units.

Alexandrium catenella cultures (VGO676 strain) were grown at $16 \pm 0.5{ }^{\circ} \mathrm{C}$ in $10-\mathrm{L}$ tanks and in Guillard's $\mathrm{F} / 2$ medium prepared with Mediterranean sea water (salinity $39 \mathrm{psu}$ ) and nutrients mix. Culture stability, i.e. a final cell concentration: 40000 cells ml$^{-1}$, was attained within 10 to 12 days using a light intensity of $135 \pm 4 \mu$ mol photons $\mathrm{m}^{-2} \mathrm{~s}^{-1}$ and a $12 \mathrm{~h} / 12 \mathrm{~h}$ photoperiod. The mean toxicity for the algal cultures, as quantified by IP-HPLC (see below) during experiments was $1.48 \pm 0.7 \mathrm{pg}$ STX eq. cell ${ }^{-1}$ (at the end of the exponential growth phase). The VGO676 toxic profile was as follows: Neo-STX, B1, B2, GTX1-4, C1-4, i.e. relatively consistent with toxin profiles observed in the field. Culture conditions (temperature, salinity, initial cell concentration, light, sampling day) were strictly identical for each trial. T. weissflogii cultures were grown in 10-L tanks in the same conditions, but using Provasoli's ES medium (1965).

\subsection{Experimental system}

The experimental system used to monitor the physiological state of each oyster in the circuit is as described in several earlier publications (Bougrier et al. 2001, 2003), slightly adapted for the purposes of this study. The system comprised twenty $0.5 \mathrm{~L}$ capacity experimental boxes, 18 containing one live oyster, and two boxes containing empty oyster shells serving as sedimentation process controls. Sea water from a $40 \mathrm{~L}$ capacity "buffer tank" was circulated through each experimental box
Table 1. Summary of the different experimental conditions. Alexandrium catenella / Thalassiosira weissflogii (Ac/Tw). Phase $1+$ Phase $2=$ one $24 \mathrm{~h}$ cycle.

\begin{tabular}{cccc}
\hline \multicolumn{2}{c}{$A c /$ Tw $\left(\right.$ cells $\left.\mathrm{ml}^{-1}\right)$} & & Ac 24 h-cycles \\
\hline Phase 1: $14 \mathrm{~h}$ & Phase $2: 10 \mathrm{~h}$ & $T\left({ }^{\circ} \mathrm{C}\right)$ & Phases $1+2$ \\
$75 / 1500$ & $150 / 1500$ & 12 & $75-150$ \\
$75 / 1500 *$ & $150 / 1500 *$ & 18 & $75-150$ \\
$150 / 1500$ & $300 / 1500$ & 18 & $150-300$ \\
$400 / 1500 * *$ & $800 / 1500 * *$ & 18 & $400-800$ \\
\hline
\end{tabular}

* Toxicity control, ** Digestive glands and other tissues analysed separately.

with an Ismatec peristaltic pump (flow rate of $150 \mathrm{ml} \mathrm{min}^{-1}$ ). And then returned to the buffer tank. During alternating 14-h and 10-h periods, two different mixed algal diets were injected into the circuit (Table 1) following an automation programme developed on LabView $(\mathbb{B}$. This LabView $®$ program maintained given cell concentrations of $A$. catenella $(A c)$ and $T$. weissflogii (Tw) in the circuit, controlling them with continuous detection of mean fluorescence in the feeding tank. The program also allowed continuous acquisition of fluorescence signals given by Turner Design Fluorometers at the output of each experimental box as well as in the buffer tank. Fluorescence measurements (in volt) were recorded on a computer as a function of time (Lassus et al. 1999, 2000).

\subsection{Chemical analyses}

Analyses of paralytic phycotoxins were performed by Ionpairing High Performance Liquid Chromatography on each individual oyster during the contamination period according to the method of Oshima et al. (1995). Every day 4 oysters were collected for analysis and new ones were put in their place. Toxicity results were thus expressed according to the time (day) during which each bivalve was fed $A c+T w$. The total quantity of flesh was ground in $\mathrm{HCl} 0.1 \mathrm{~N}$ at $4{ }^{\circ} \mathrm{C}$ on a v/w basis. After centrifugation $\left(3000 \mathrm{~g}, 15 \mathrm{~min}, 4^{\circ} \mathrm{C}\right), \mathrm{pH}$ of extracts was adjusted to $3.0-3.5$ with glacial acetic acid. After dilution, the supernatants were ultra filtrated $(20000 \mathrm{Da}$, Sartorius Centrisart) and stored at $4{ }^{\circ} \mathrm{C}$ until analysis. For A. catenella cultures, $10 \mathrm{ml}$ pipette extractions were made at the end of the exponential phase. The cells were counted on hematimetric cells, and the samples were centrifuged $(3000 \mathrm{~g}, 15 \mathrm{~min}$, $4{ }^{\circ} \mathrm{C}$ ). After removal of the supernatant, acetic acid $0.1 \mathrm{~N}$ was added to the pellet and the cells were broken up by a freezing / thawing method.

Solutions of each compound of a PSP1-C reference material (IMB, NRC-Halifax, Canada) were diluted 1:200 and used as external standards for quantitative detection. Given the dilution factors, the molar concentration was converted into $\mu \mathrm{g}$ STX eq. $100 \mathrm{~g}^{-1}$ of oyster flesh by using the conversion factors of Oshima (1995), i.e. $297 \mu \mathrm{g}$ STX eq. $\mu \mathrm{M}^{-1}$ for GTX3, 168 for GTX2, 48 for C1 and C2, 28 for B1 and 354 for GTX4. When no toxin standards were commercially available, acid hydrolysis of the extracts was carried out to convert $\mathrm{N}$-sulfocarbamoyl into carbamate (Masselin et al. 2001). 


\subsection{Physiological analyses}

Diurnal mean retention rates (RR) were calculated by means of discrete counting of the cell concentrations of each algal species at the output of experimental tanks. These values were compared to cell concentrations at the output of control tanks as follows:

$\mathrm{RR}=100\left(c_{0}-c\right) / c_{0}$, where $c$ and $c_{0}$ are algae concentrations at the output of the experimental tank and the control tank (general input) respectively.

This retention rate can easily be transformed into a clearance rate $(\mathrm{CR})$ by introducing a flow rate $(D)$ as follows:

$$
\mathrm{CR}=\mathrm{RR} . D
$$

Using fluorescence continuous monitoring and multiple linear regression between fluorescence units and cell concentrations, it was possible to express:

$\mathrm{FLUO}=a A c=b T w$ where $A$. catenella $(A c)$ and $T$. weissflogii (Tw) in cells $\mathrm{L}^{-1}$ and, later on, to convert the differences between control and experimental tank fluorescence into a number of $A c$ and $T w$ cells taken up from the water by each oyster.

Knowing the mean toxin content per cell, it was therefore possible to determine the corresponding amount of toxin "sampled" by the oyster, i.e. $Q_{\text {tox }}$, expressed as follows:

$$
Q_{\text {tox }}=\theta\left(D\left(A c_{0}-A c\right)-\mathrm{d} A c / \mathrm{d} t\right)
$$

$\theta$ : mean toxin content per $A c$ cell, $D$ : flow rate, $A c$ and $A c_{0}$ : cell concentrations respectively at the output and at the input (control) of the system.

As each oyster may rapidly move from one state of equilibrium (e.g. no filtration) to another state of equilibrium (filtration) and inversely, the $\mathrm{d} A c / \mathrm{d} t$ factor (sharp $A c$ changes at the beginning of food uptake) may be considered negligible.

The $y$ ratio, $y=A c / T w$ can be considered as constant for a $24 \mathrm{~h}$ cycle since the oyster did not reveal (see further results) any pre-ingestive selection between each algal species. Thus, $y=A c / T w=A c_{0} / T w_{0}$.

The $y$ value may change for each $24 \mathrm{~h}$ cycle, it seemed worth replacing $T w$ by its other value: $A c / y$ and expressing another form of fluorescence equation:

FLUO $=a A c+(b A c) / y$ which means $A c=\mathrm{FLUO} /(a+b / y)$.

If the same transformations are applied to $A c_{0}$, then a new expression for $Q_{\text {tox }}$ is:

$$
Q_{\mathrm{tox}}=\theta D\left(\mathrm{FLUO}_{0}-\mathrm{FLUO}\right) /(a+b / y) \text { in } \mu \mathrm{g} \mathrm{STX} \mathrm{eq.}
$$

When this value is multiplied by 100 and divided by the oyster weight, the amount of toxin (in $\mu \mathrm{g}$ STX eq. $100 \mathrm{~g}^{-1}$ ) taken up by the oyster can be calculated.

The estimator for Ingested Toxin Rate (ITR) can be expressed by:

$$
\text { ITR }=\beta Q_{\text {tox }} \text { if } \beta=(\mathrm{F}-\mathrm{PF}) / \mathrm{F}
$$

where $\mathrm{F}$ and PF are the amounts of faeces and pseudo-faeces respectively excreted by the oyster, when $\mathrm{PF}=0, \beta=1$ and $\operatorname{ITR}=Q_{\text {tox }}$.

\subsection{Analysis and models}

A one-compartment model was proposed by Silvert et al. (1998). This model presumes that shellfish feeding behaviour can be considered as uniform, and thus can be applied to the whole body on the assumption that all tissues are contaminated in the same way:

$$
\mathrm{dC} / \mathrm{d} t=\mathrm{ITR}-\alpha \mathrm{C}
$$

where C: toxin concentration in $100 \mathrm{~g}$ oyster flesh, ITR: ingested toxin rate in $\mu \mathrm{g}$ STX eq. $100 \mathrm{~g}^{-1}$ day $^{-1}$ $\alpha$ : detoxification coefficient.

For the two-compartment model, detoxification is considered as a two-step process, with a first rapid step corresponding to the excretion of non-absorbed toxins from the digestive tract (compartment 1) and a second slow step corresponding to the elimination of toxins bound to oyster tissues (compartment 2). This model was used for mussels (Blanco et al. 1997) and for scallops (Chen and Chou 2001). From these observations, it was decided to try a contamination/detoxification model based upon two distinct compartments interacting each other and detoxifying with different detoxification rates:

$$
\begin{aligned}
& \mathrm{dC}_{1} / \mathrm{d} t=\mathrm{ITR}-\alpha \mathrm{C}_{1}-\mathrm{T}_{1-2} \mathrm{C}_{1} \\
& \mathrm{dC}_{2} / \mathrm{d} t=\mathrm{T}_{1-2} \mathrm{C}_{1}-\beta \mathrm{C}_{2} \\
& \mathrm{C}=\mathrm{C}_{1}+\mathrm{C}_{2}
\end{aligned}
$$

where $\mathrm{C}_{1}$ and $\mathrm{C}_{2}$ : toxin concentrations for compartments 1 and 2 , respectively,

$\alpha$ and $\beta$ : detoxification coefficients for compartments 1 and 2, respectively,

$\mathrm{T}_{1-2}$ : transfer rate from compartment 1 to compartment 2 .

\section{Results}

\subsection{Angle Creek observations (24h survey)}

In October 2003, a sharp increase in A. catenella concentrations at Angle Creek and Bouzigues (Thau Lagoon) led to PSP contamination of oysters and mussels up to levels exceeding the regulatory threshold (Fig. 2). An increase in A. catenella concentrations at the Bouzigues station was subsequently observed in late September, leading up to a peak concentration of 188 cells $\mathrm{ml}^{-1} 15$ days later, and then in late October a rapid decline of the bloom. A maximum paralytic toxin concentration $\left(318 \mu \mathrm{g}\right.$ STX eq. $\left.100 \mathrm{~g}^{-1}\right)$ was detected in oysters a few days before the A. catenella peak concentration. However, sea water samples and shellfish were collected at the same time and at the same place by operators in charge of the monitoring network This observation could possibly be explained by a slow but constant uptake of toxins by oysters from low concentrations of Alexandrium over a period of time before this observation was made.

The $24 \mathrm{~h}$ sampling cruise set up on 7 and 8 October 2003, i.e. during the period of maximum toxicity in shellfish, revealed steady salinities ( 38.5 to 38.8 psu in surface samples and 39.2 psu at the bottom), consistent minimum and maximum temperatures of $16.6{ }^{\circ} \mathrm{C}$ and $18.3{ }^{\circ} \mathrm{C}$, with almost no 


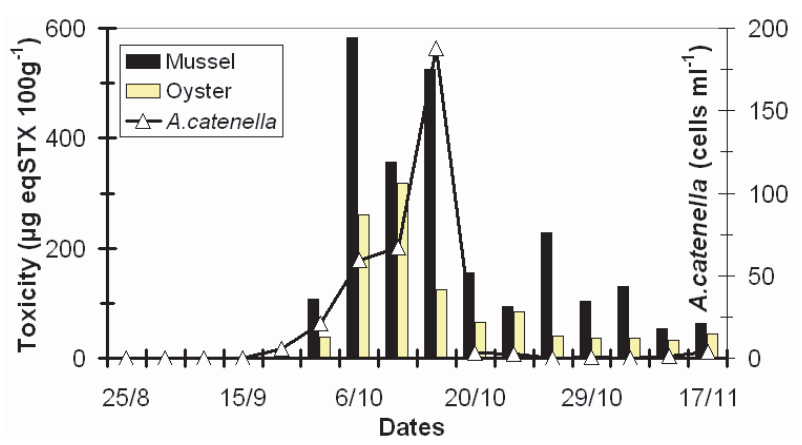

Fig. 2. Compared toxicity changes in oysters and mussels together with Alexandrium catenella concentrations at the same site (Bouzigues oyster bed) during the October-November 2003 toxic outbreak (in situ observations).

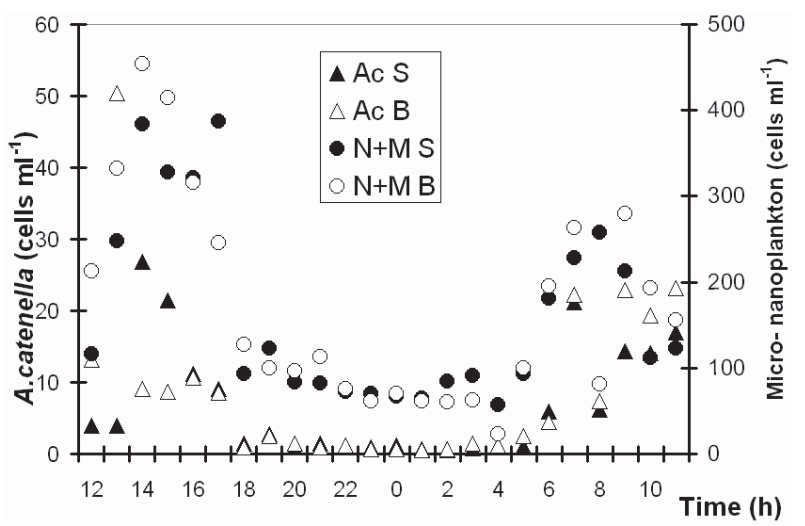

Fig. 3. 24-hour variations of A. catenella (Ac) and nano+microplankton $(\mathrm{N}+\mathrm{M})$ concentrations, sea surface $(\mathrm{S})$ and bottom (B). In situ observations.

difference recorded between surface and bottom waters, and, finally, stable fluorescence values on the bottom.

Observation of water samples showed picoplankton $(\leq 2 \mu \mathrm{m})$ was the dominant size fraction during the whole of the sampling cruise with a slight time-related decreasing trend, and cell concentrations dropping from 80000 to 15000 cells $\mathrm{ml}^{-1}$. The dominant species for the nanoplankton ( 2 to $20 \mu \mathrm{m})$ size fraction was Thalassiosira sp. $(7 \times 10 \mu \mathrm{m})$, immediately followed by several species of Chaetoceros, an unidentified Cryptophyceae and Skeletonema costatum. Finally, microplankton (20 to $200 \mu \mathrm{m})$ diversity was low with chain-forming diatoms belonging to Pseudo-nitzschia and Thalassionema genera, a silicoflagellate (Ebria tripartita) and some dinoflagellates belonging to the Gonyaulax, Gymnodinium and Prorocentrum genera. A. catenella was observed as single cells or colonial forms with chains of 2, 3, 4 or even 6 cells, exceptionally, with a mean cell size of $28 \times 32 \mu \mathrm{m}$, and in situ cell concentrations varying from 500 to 50000 cells $\mathrm{L}^{-1}$.

The 24-hour survey revealed a nano- and microplankton decrease during the night with a similar, although more pronounced, pattern for A. catenella (Fig. 3). There were no significant differences in cell concentrations between surface and bottom waters except on 7 October 2003 at $1.00 \mathrm{pm}$, with a switch at $2.00 \mathrm{pm}$ and $3.00 \mathrm{pm}$, A. catenella surface

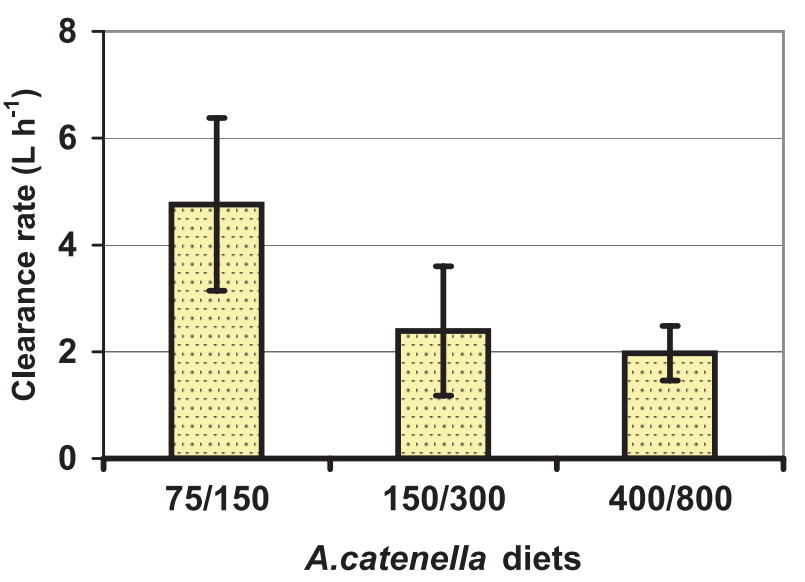

Fig. 4. Mean clearance rates of oysters fed on different mixed Ac/Tw diets on the $4^{\text {th }}$ day of contamination.

concentrations being 2.5 to 3 times higher than bottom concentrations. The ratio A. catenella / nano + microplankton hardly varied at all (1.5-3\%) at the bottom between $4.00 \mathrm{pm}$ and $5.00 \mathrm{am}$, but bottom cell concentrations were representing a consistent proportion of microplankton (8-13\%) at the beginning and end of the observation period, i.e. at the times corresponding to maximum $A$. catenella concentrations.

\subsection{Laboratory simulations}

From in situ observations, several laboratory trials were performed (Table 1) so as to simulate the effects of two temperatures and three kinds of $A c / T w$ mixed diets. Clearance rates revealed higher food particle retention at $18{ }^{\circ} \mathrm{C}$ than at $12{ }^{\circ} \mathrm{C}$, corroborating the established impact elevated temperature has on feeding activity and therefore on toxin uptake.

Moreover, the relationship between clearance rates and A. catenella concentrations (Fig. 4) showed that the 75-150 and 150-300 cycles were significantly different (ANOVA, $p<0.05$ ) and the same was true for the 75-150 cycle as compared with the 400-800 cycle. Conversely, there was no significant difference $(p=0.07)$ between the 150-300 and 400-800 cycles.

Comparison by Coultronics $(\mathbb{R}$ system of the relative ratios $A c / T w$ (Fig. 5) in pseudo-faeces and in recirculated sea water did not show any significant difference, whatever the $A$. catenella concentration tested (75 or 150 cells $\mathrm{ml}^{-1}$ ). Similar results were obtained at 12 or $18^{\circ} \mathrm{C}$ and this would tend to defend the hypothesis that $A$. catenella is not significantly more eliminated in pseudo-faeces than Thalassiosira weissflogii and, hence, that no pre-ingestive selection does occur.

IP-HPLC results regarding bioaccumulation patterns in oyster flesh showed, for the most toxic analogs, GTX1-4 epimers and Neo-STX as predominant compounds, an overall toxicity below the regulatory level after 4 days contamination at $12{ }^{\circ} \mathrm{C}$, whereas at $18{ }^{\circ} \mathrm{C}$ (Fig. 6) the safe threshold is exceeded right from day 1 of contamination. This kind of observation will not be repeated for the various experiments on the effects of $A$. catenella concentrations: significant but low difference between $A c$ 75-150 and 150-300 cycles, no significant difference between Ac 150-300 and 400-800 cycles. In 


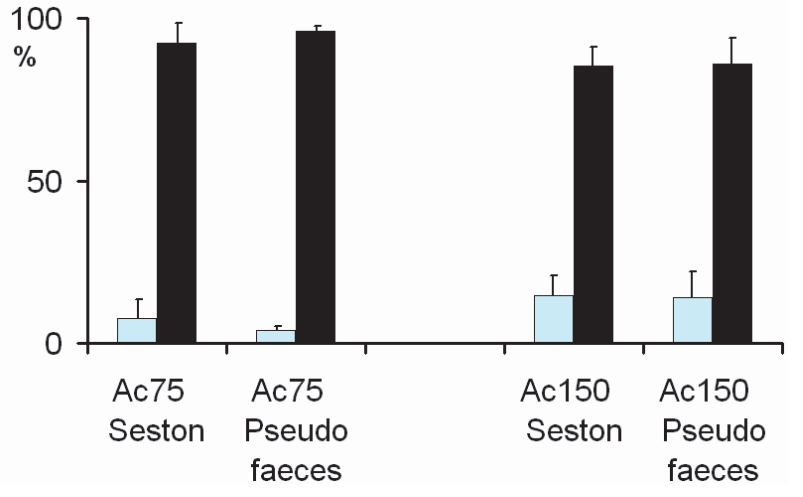

Fig. 5. Relative percentages of A. catenella (white bars) and T. weissflogii (black bars) in pseudo-faeces (PF) and seston at $18{ }^{\circ} \mathrm{C}$ and for the Ac $75-150$ cycles.

the first case, the regulatory threshold is reached within 4 days whereas in the second example, final toxicities at day 4 are all lower than the $80 \mu \mathrm{g}$ STX eq. $100 \mathrm{~g}^{-1}$ threshold. $Q_{\text {tox }}$ simulations (Figs. 7a,b) enabled us to confirm these observations and to feature more precisely the mean evolution of toxins content in oyster for each diet under consideration. These results tend to indicate a probable inhibition of oyster clearance rates at highest Ac concentrations (400-800 diet).

In terms of toxin profiles in A. catenella cultures as well as in PSP contaminated shellfish, the results showed overall toxin content in phytoplankton varying widely (up to 200\%) according to the type of trial. No clear explanation of these variations could be given since growing conditions were kept unchanged, particularly temperature, which variations may consistently modify A. catenella toxin content (Navarro et al. 2006). However, the toxin profile was maintained with relatively few changes in the A. catenella VGO676 strain with the following profile: $\mathrm{C} 1$ to $\mathrm{C} 4 \gg \mathrm{B} 2=\mathrm{GTX} 1-4>\mathrm{NeoSTX}>$ GTX2-3 > B1.

This resulted, for the different trials, in toxin profiles in oysters that were either slightly different, or not different at all, at day 4 of contamination. Epimers C1 and GTX1 were only detectable at trace levels. Besides, some discrepancies could be observed according to the season of the experiment (Fig. 8). For instance, in November 2004 (75-150 and 150-300 cycles) the proportion of NeoSTX increased to up to $21 \%$ of total toxin amount expressed as molar weight, whereas the B2 proportion decreased. This toxin profile was significantly different from A. catenella toxin profile at the time of the experiment. NeoSTX intrinsic toxicity is among the highest, according to Oshima (1995).

Looking at the Ac 400-800 cycles and the respective contributions of muscle, digestive gland and other tissues to overall toxicity (toxin body burden), it could be clearly seen that highest toxicities were recorded in the digestive gland, i.e. $565 \mu \mathrm{g}$ STX eq. $100 \mathrm{~g}^{-1}$ at day 4. Mean toxin contents of muscle and other tissues (mantle, gills, heart) were 4.1 and $18.5 \mu \mathrm{g}$ STX eq. $100 \mathrm{~g}^{-1}$ respectively. The weight contribution of digestive gland to total oyster flesh was $16.0 \pm 0.5 \%$, which explains the predominant role played by the digestive gland as regards total toxicity.

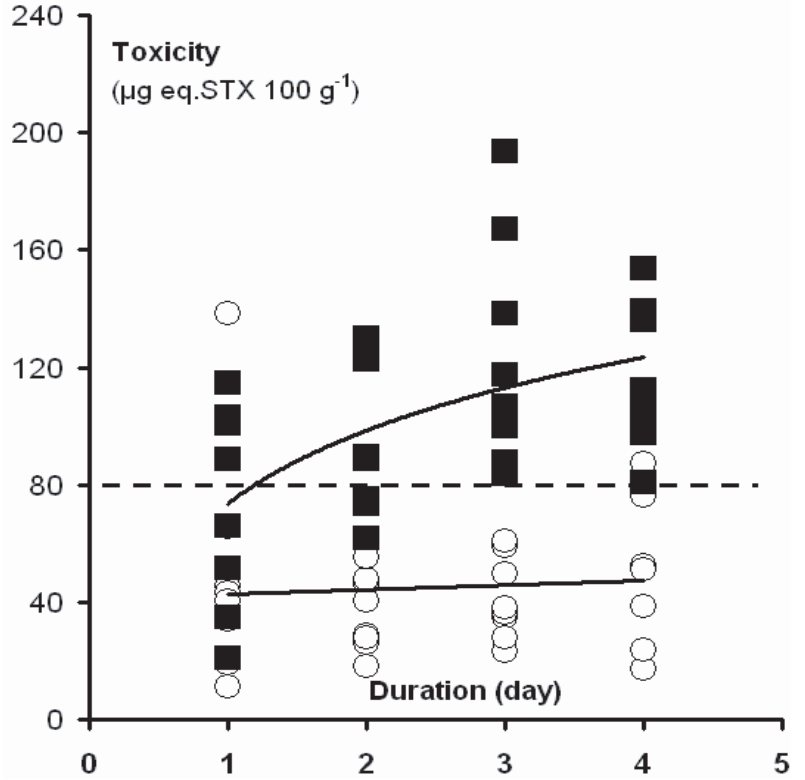

Fig. 6. Toxicity trends over 4 days' contamination at $12{ }^{\circ} \mathrm{C}$ (open circles) and $18{ }^{\circ} \mathrm{C}$ (plain squares) for the $A c 75-150$ cycle. Individual toxicities of sampled oysters are represented.

To optimize the toxin uptake simulation, two bioaccumulation models (one- and two-compartment models) were tested on the basis of $Q_{\text {tox }}$ expression, this being the best way to arrive at a correct description of the contamination process dynamic. Comparison was made with data obtained at $18{ }^{\circ} \mathrm{C}$ from the Ac 400-800 trial (Figs. 9a,b). The detoxification coefficient $\alpha$ was 47.3 for the one-compartment model (Fig. 9a), with a square deviation equal to 1549 . This model produced wide variations, and a less than satisfactory match with toxicity data deriving from the chemical analysis of oyster samples (observed values). In the two-compartment model (Fig. 9b), the $\alpha$ and $\beta$ detoxification coefficients were 203 and 2.2 respectively. The square deviation between this model and observed values was 101 . This second model was therefore more closely aligned with the real toxicity values than the previous one, and it indicated that most of the bioaccumulation process was linked to the compartment theoretically representing the digestive gland.

\section{Discussion}

The 24-h survey of $A$. catenella concentrations in the North East part of Thau Lagoon showed that this species (maximums of 50000 and 28000 cells $\mathrm{L}^{-1}$ respectively in bottom and surface waters) did not dominate the other phytoplankton species. Local microflora consisted mainly of pico- and nanoplankton species. The diatom Thalassiosira weissflogii was therefore chosen as a non-toxic representative of nanoplankton populations, and used as a complementary algal food during several experimental contamination trials based upon increasing proportions of toxic A. catenella strain in the mixed diet. A significant effect of temperature upon paralytic toxin accumulation rates in oysters was clearly demonstrated: at $18{ }^{\circ} \mathrm{C}$, the regulatory threshold was exceeded as early as the first day of 

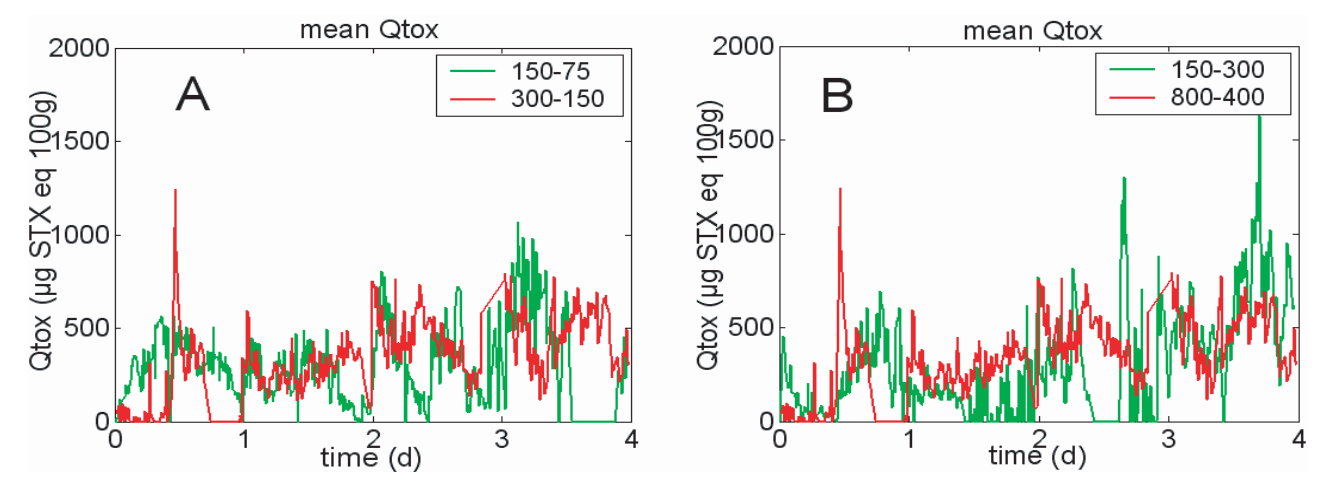

Fig. 7. Amounts of toxins $\left(Q_{\text {tox }}\right)$ taken up by the oyster during the 4 days contamination process and for compared $A c$ cycles $75-150$ versus 150-300 (left) and 150-300 versus 400-800 (right).

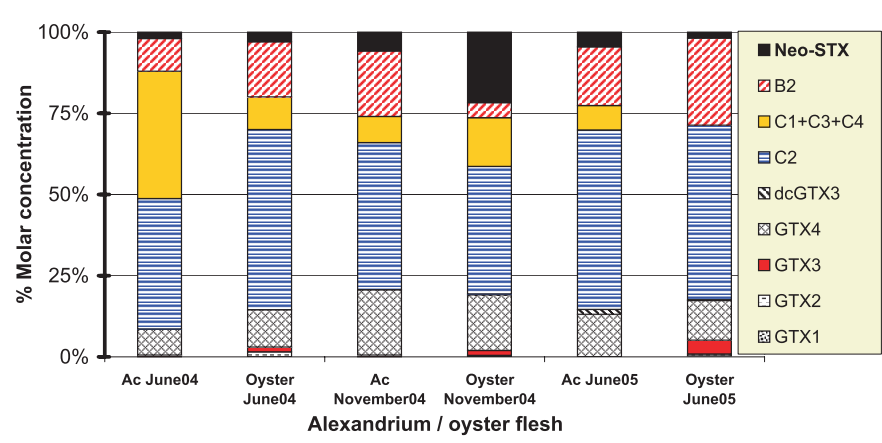

Fig. 8. Mean percentages of STX or NeoSTX analogs calculated from molar weights in $4 \mathrm{~d}$ contaminated oysters and in A. catenella cultures (Ac) used for each experiment. June 2004: Ac 75-150 at $12{ }^{\circ} \mathrm{C}$ and $18^{\circ} \mathrm{C}$, November 2004: $A c 75-150$ and $150-300$ at $18^{\circ} \mathrm{C}$, June 2005 : Ac $150-300$ and $400-800$ at $18{ }^{\circ} \mathrm{C}$.

contamination, whereas at $12{ }^{\circ} \mathrm{C}$, it was never reached, even after 4 days. This result needs to be considered together with the fact that clearance rates are higher at $18{ }^{\circ} \mathrm{C}$ than at $12{ }^{\circ} \mathrm{C}$, which is in agreement with Bougrier et al. (1995) who cited a $19{ }^{\circ} \mathrm{C}$ optimum value for $C$. gigas clearance activity. This physiological reaction leads to increased filtration and ingestion rates, and finally to increased toxin uptake as already observed by some investigators (Bricelj et al. 1990; Bricelj and Shumway 1998). Moreover, for both, these experimental temperatures, identical toxic and non toxic cell proportions in either feeding water or oyster pseudo-faeces indicated that no pre-ingestive selection occurred.

Regarding the impact of $A$. catenella concentrations in the mixed algal diet it appeared that the most toxic ratio (Ac 150-300 and 400-800) significantly slowed down food uptake, which was reduced by one half when compared to Ac 75-150. At the same time, no significant difference was observed between the two highest ratios. Overall toxicity of oysters fed with these different diets varied in a similar way: there was a significant toxin content increase when shifting from $A c 75-150$ to $150-300$, but no significant difference between Ac 150-300 and 400-800. These results would support the hypothesis of a "threshold effect", i.e. a threshold toxic alga concentration that would cause inhibition of filtration activity and subsequently a decrease in toxin uptake. Experimental simulations of oyster PSP contamination by A. minutum in
Northern Brittany (Lassus et al. 2004; Baron et al. 2006) led to the same conclusions.

As for the role of oyster tissues in toxin bioaccumulation patterns, it seems clear, as already showed by other investigators (Bricelj and Shumway 1998; Lassus and Marcaillou-Le Baut 2001) that toxin accumulation in the digestive gland represents $80 \%$ or more of the body's toxin burden. Despite low toxicity values in muscle and other tissues, some trend reversals at day 4 contamination emphasized the possibility of toxin transfer or sequestering in tissues other than those of the digestive gland (Cembella et al. 1993, 1994; Oshima 1995).

There was no significant difference between toxin profiles of A. catenella cultures and oyster tissues after 4 days contamination as far as experimental parameters (cell concentrations, temperature) were concerned. Conversely, and even if triploid oysters were used, it seems a seasonal effect could be suspected since in all November trials (and in contrast to the June trials) NeoSTX proportions were found to be increasing whereas the levels of B2 were decreasing. Further monitoring is required to corroborate this observation and explore a possible early toxin biotransformation, which, if confirmed, would constitute an unusual bioconversion pathway. Some authors (Samsur et al. 2006) documented the appearance of NeoSTX in Tapes japonica fed A. catenella, although carbamate toxins were not found in A. catenella cultures.

These different observations together with fluorescence continuous recording at the outlet of each experimental box containing an oyster permitted $Q_{\text {tox }}$ calculation, i.e.; calculation of the amount of toxin taken up by the oyster. One- or two-compartment models were tested according to the view adopted of the bioaccumulation kinetic: whether it was regarded as a global process involving all shellfish tissues, or as a two-step process where toxins could be found to be 'free moving' in the digestive tract, without having undergone any chemical transformation, or without being bound to oyster tissues and therefore subject to biotransformation processes. The results showed that the contamination process could be simulated with a one-compartment model based on A. catenella mean cell toxicity and the $A$. catenella/microplankton ratio. It appeared that the best fit with the observed contamination kinetic was obtained with a two-compartment model, however, and even though the $Q_{\text {tox }}$ method slightly over-estimated the real amount of ingested toxins. This result for the Pacific 

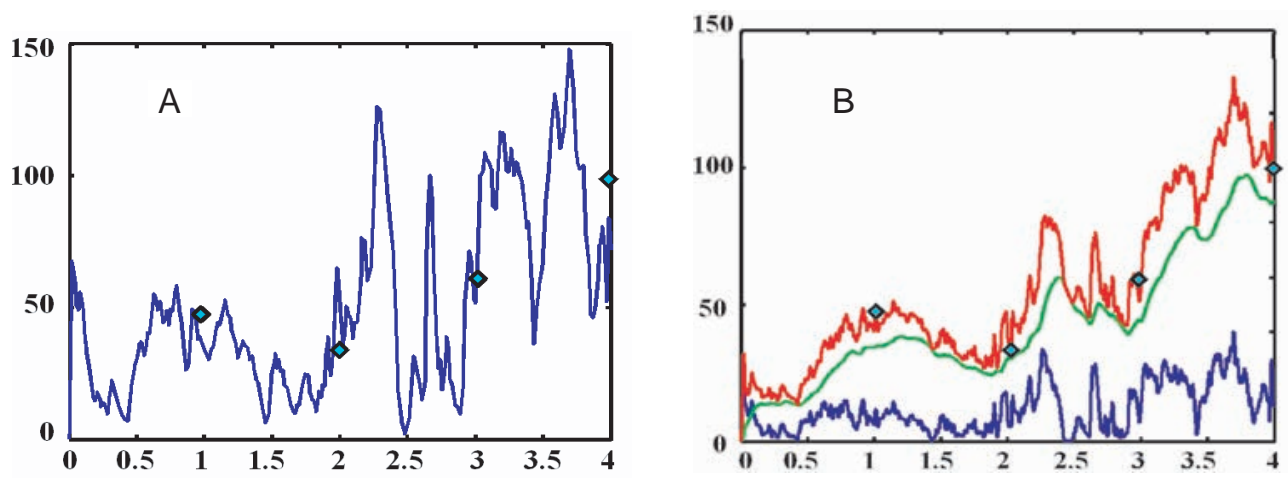

Fig. 9. Amount of toxin per oyster $\left(Q_{\text {tox }}\right)$ change simulations ( $\mu$ g STX eq. $100 \mathrm{~g}^{-1}$ ) over 4 days, according to a one-compartment model (left) and to a two-compartment model (right) for $A c 400-800$ cycles at $18{ }^{\circ} \mathrm{C}$. Stars represent toxicity values actually observed, for the onecompartment model. For the two-compartment model, the lowest curve relates to toxins bound to tissues other than those of the digestive gland, the intermediate curve to toxins contained within the digestive gland, and the upper curve to the model.

oyster may be worth comparing with PSP accumulation models in mussels (Moroño 2000; Moroño et al. 1998) and especially with the two-compartment model used by Yamato et al. (2003) to simulate a PSP contamination/detoxification process in $C$. gigas. This last trial seemed to yield sufficiently satisfying results for them to be taken into consideration during field applications when assessing Alexandrium concentrations directly from sea water samples.

Acknowledgements. The authors are particularly grateful to the National Program for the Coastal Environment (PNEC) for their financial support for this study. They also wish to thank Dr Santiago Fraga (IEO Vigo) for having isolated and grown in culture the VGO676 A. catenella strain, and, finally they address special thanks to Bernard Raffin for the chart he created of Thau Lagoon.

\section{References}

Baron R., Couedel M., Joret C., Garen P., Truquet P., Masselin P., Bardouil M., Lassus P., 2006, Continuous fluorescence recording as a way to improve Pacific oyster (Crassostrea gigas) models of paralytic shellfish toxin accumulation. Aquat. Living Resour. 19, 77-84.

Blanco J., Moroño A., Franco J., Reyero M.I., 1997, PSP detoxification kinetics in the mussel Mytilus galloprovincialis. One- and two- compartment models and the effect of some environmental variables. Mar. Ecol. Prog. Ser. 158, 165-175.

Bougrier S., Geairon P., Deslous-Paoli J.M., Bacher C., Jonquières G., 1995, Allometric relationships and effects of temperature on clearance and oxygen consumption rates of Crassostrea gigas (Thunberg). Aquaculture 134, 143-154.

Bougrier S., Lassus P., Bardouil M., Masselin P., Truquet P., 2003, PSP accumulation yields and feeding time activity in the Pacific oyster (Crassostrea gigas) and king scallop (Pecten maximus). Aquat. Living Resour. 16, 347-352.

Bougrier S., Lassus P., Beliaeff B., Bardouil M., Masselin P., Truquet P., Matignon F. 2001, Feeding behaviour of individuals and groups of king scallops (Pecten maximus) contaminated experimentally with PSP toxins and detoxified. In: Hallegraeff G.M., Blackburn S.I., Bolch C.J., Lewis R.J. (Eds.) Harmful algal Blooms 2000, IOC-Unesco, pp. 407-410.
Bricelj V.M., Lee J.H., Cembella A.D., Anderson D.M., 1990, Uptake kinetics of paralytic shellfish toxins from the dinoflagellate Alexandrium fundyense in the mussel Mytilus edulis. Mar.Ecol. Prog. Ser. 63, 177-188.

Bricelj V.M., Shumway S.E. 1998, Paralytic shellfish toxins in bivalve molluscs occurrence, transfer kinetics, and biotransformation. Rev. Fish. Sci. 6, 4 315-383

Cembella A.D., Shumway S.E., Lewis N.I., 1993, Anatomical distribution and spatio-temporal variation in paralytic shellfish toxin composition in two bivalves species from the Gulf of Maine. J. Shellfish Res. 12, 389-403.

Cembella A.D., Shumway S.E., Larocque R., 1994, Sequestering and putative biotransformation of paralytic shellfish toxins by the sea scallops Placopecten magellanicus: seasonal and spatial scales in natural populations. J. Exp. Mar. Biol. Ecol. 180, 1-22.

Chen C.Y, Chou, H.N, 2001. Accumulation and depuration of paralytic shellfish poisoning toxins by purple clam Hiatula rostrata Lighttoot. Toxicon 39, 1029-1034.

Honsell G., Poletti R., Pompei M., Sidari L., Milandri A., Casadei C., Viviani R., 1996, Alexandrium minutum Halim. and PSP contamination in the Northern Adriatic Sea (Mediterranean sea). In: Yasumoto T., Oshima Y., Fukuyo Y. (Eds.). Harmful and Toxic Algal Blooms, IOC-Unesco, pp. 77-80.

Joutei L.T., 1998. Gymnodinium catenatum Graham blooms on Moroccan waters. In: Reguera B., Blanco J., Fernandez M.L.,Wyatt T. (Eds.). Harmful Algae, Xunta de Galicia and IOCUnesco, pp. 66-67.

Laabir M., Génovési-Giunti B., Barré N., Vaquer A., Collos Y., Erard-Le Denn E., Cecchi P., Pons V., Bilbent B., 2004, The resting cyst of Alexandrium catenella a dinoflagellate responsible for Harmful Algal Blooms in Thau Lagoon (Western French Mediterranean coast). In: Steidinger K.A., Landsberg J.H., Tomas C.R., Vargo G.A. (Eds.) Harmful Algae 2002, Florida Fish and Wildlife Conservation Commission, Florida Institute of Oceanography and IOC-Unesco, pp. 26-28.

Lassus P., Abadie E., Amzil Z., Belin C., Comps M.A., ElzièrePapayanni P., Le Bec C., Marcaillou-Le Baut C., Nezan E., Poggi R., 1999, Contamination de l'étang de Thau par Alexandrium tamarense. Ifremer, Bilans et prospectives. 
Lassus P., Baron R., Garen P., Truquet P., Masselin P., Bardouil M., Leguay D., Amzil Z., 2004, Paralytic shellfish poison outbreaks in the Penzé estuary: environmental factors affecting toxin uptake on oyster Crassotrea gigas. Aquat. Living Resour. 17, 207-214.

Lassus P., Marcaillou-Le Baut C., 2001, Contamination, transformation et détoxication des produits marins. In: Lassus P., Frémy J.M. (Eds.) Toxines d'algues dans l'alimentation, Ifremer-AFSSA, pp. 403-446.

Lilly E.L., Kulis D.M., Gentien P., Anderson D.M., 2002, Paralytic Shellfish Poisoning toxins in France linked to a humanintroduced strain of Alexandrium catenella from the western Pacific: evidence from DNA and toxin analysis. J. Plankton Res. 24, 443-452.

Masselin P., Amzil Z., Abadie E., Carreras A., Chiantella C., Le Bec C., Nézan E., Truquet P., 2001. Paralytic shellfish poisoning on the French Mediterranean coast in autumn 1998: Alexandrium tamarense complex (Dinophyceae) as causative agent. In: Hallegraeff G.M., Blackburn S.I., Bolch C.J. Lewis R.J. (Eds.) Harmful Algal Blooms 2000, IOC-Unesco, pp. 26-29.

Moroño A., 2000, Cinética de intoxicación de toxinas PSP en Mytilus galloprovincialis Lmk., Tesis de doctorado, Universidad de Santiago de Compostela.

Moroño A., Maneiro J., Pazos Y., Blanco J., 1998, Modelling the accumulation of PSP toxins in Galician mussels: results and perspectives, In : Reguera B., Blanco J., Fernández M.L., Wyatt T. (Eds.) Harmful Algae, Xunta de Galicia and IOC-Unesco, pp. 441-444.
Navarro J.M., Muñoz M.G., Contreras A.M., 2006. Temperature as a factor regulating growth and toxin content in the dinoflagellate Alexandrium catenella. Harmful Algae 5, 762-769.

Oshima Y., 1995, Chemical and enzymatic transformation of paralytic shellfish toxins in marine organisms. In: Lassus P., Arzul G., Erard E., Gentien P. Marcaillou C. (Eds.) Harmful Algal Blooms, Lavoisier, pp. 475-480.

Samsur M., Yamaguchi Y., Sagara T., Takatani T., Arakawa O., Noguchi T., 2006. Accumulation and depuration profiles of PSP toxins in the short-necked clam Tapes japonica fed with the toxic dinoflagellate Alexandrium catenella. Toxicon 48, 323-330.

Silvert W., Bricelj M., Cembella A. 1998, Dynamic modelling of PSP toxicity in the surfclam (Spisula solidissima): multicompartmental kinetics and biotransformation. In: Reguera B., Blanco J., Fernandez M.L., Wyatt T. (Eds.) Harmful Algal Blooms. IOCUnesco, pp. 437-440.

Vila M., Delgado M., Camp J., 2001, First detection of widespread toxic events caused by Alexandrium catenella in the Mediterranean sea. In: Hallegraeff G.M., Blackburn S.I., Bolch C.J., Lewi R.J. (Eds.) Harmful Algal Blooms 2000, IOC-Unesco, pp. 8-11.

Vila M., Garcés E., Masó M., Camp J., 2001, Is the distribution of the toxic dinoflagellate Alexandrium catenella expanding along the NW Mediterranean coast? Mar. Ecol. Prog. Ser. 222, 73-83.

Yamamoto T., Flynn K.J., Takayama H., 2003, Application of a twocompartment one-toxin model to predict the toxin accumulation in Pacific oysters in Hiroshima Bay, Japan. Fish. Sci. 69, 944-950. 